\title{
THE CENTENARY OF 'DARWINISM'
}

T

HE Linnean Society has issued a special number of its journals in celebration of the centenary of the first publication of the theory of evolution by natural selection in the papers by Darwin and Wallace given to the Society in 1858*. The number contains thirteen papers, mostly by Fellows of the Society. Three of these deal with Darwin and the development of his theory during the intervening century, and the rest with modern work on evolution, five botanical and five zoological.

The first of the three contributions on Darwin's life and theory is Sir Julian Huxley's lecture on "The Emergence of Darwinism", which was given at the inaugural meeting of the fifteenth International Congress of Zoology last July. The lecture is an evaluation of Darwin's work in the light of our more recent knowledge. In particular, Huxley stresses the part of good fortune in Darwin's career, especially in providing him with the background required for his work. Even his delay in publishing his theory was fortunate, for the world was not ready for it earlier. So also was the intervention of Wallace, without which he might never have published, or, at least, not in the readable form in which it appeared. The lecture gave a most appropriate introduction to the Congress-as it also does to this publication-in emphasizing Darwin's outstanding quality as a biologist, not always sufficiently appreciated in modern times.

In his essay on Darwin's views on embryology and evolution, Sir Gavin de Beer discusses chiefly how far Darwin believed in Haeckel's theory of recapitulation. In the first edition of "The Origin" he was unwilling to accept the essential thesis of the theory, that lifehistories evolve by addition of new stages at their ends, but he seems to have been persuaded by Fritz Müller and Haeckel to a still somewhat cautious acceptance, being in this matter led astray, perhaps because he realized that his knowledge of embryology was not wide. de Beer also believes that in at least one quotation Darwin anticipates the theory of pædomorphosis. This seems, to me, at least doubtful ; the quotation can be read as doing no more than express doubts about the more extreme forms of the recapitulation theory.

* Darwin-Wallace Centenary. J. Linn. Soc., Lond. Botany, 56 No. 365; Zoology, 44, No. 205: pp. 1-152 (1958).
In his article on "Darwin, Wallace and 'Pre. adaptation'", Dr. Harrison Matthews discusses the intellectual climate at the time of the publication of "The Origin", emphasizing, as did Sir Julian Huxley, the value to Darwin of the progress of thought in the preceding years and of the fact that in 1859 -but not ten years earlier-younger men such as T. $H$. Huxley were available to support the new theory.

As a zoologist and not a botanist, $I$ cannot discuss the botanical papers in detail. In his presidential address on fossil plants, Dr. Hamshaw Thomas gives an account of a great deal of recent work and shows that much evolution in plants has been by development of new structures rather than by modification of structures already present--the parts of the flower are not modified leaves. Dr. W. B. Turrill in his Hooker Lecture discusses the evolution of floras, with special reference to the Balkan peninsula; Dr. E. J. H. Corner has a paper on change of function in the organs of plants and the part it has played in evolution; Prof. I. Manton writes on chromosome numbers and the phylogeny of ferns; and Dr. Darnley Gibbs on the production of chemical substances in plants.

The longest of the zoological papers is Dr. S. M. Manton's summary of her work on locomotion in the arthropods. This will be useful to many who are not specialists in the subject and find her original papers longer than they can absorb. Prof. O. M. B. Bulman has an interesting paper on the evolution of colonial form in the graptolites, and Dr. E. B. Ford writes on the work of the Oxford zoologists on evolution in natural populations. In a paper on the problems of reptile classification, Mr. F. R. Parrington discusses much recent work and comes to the conclusion that there is no reason for thinking the reptiles diphyletic ; all their groups are descended from primitive captorhinomorphs which were already reptiles. Finally, Dr. G. Pontecorvo writes on the versatility in evolution shown by the hereditary systems of organisms, both in typical holozygotic reproduction and in more primitive types.

Anyone interested in one or more of the many subjects dealt with in these papers will find something of value in this publication. It seems an excellent way to celebrate the centenary.

G. S. Carter

\section{WATER FLUORIDATION AND DENTAL CARIES}

$\mathrm{T}$ HE Swedish Royal Medical Board has submitted a report to H.M. The King of Sweden concerning the use of fluorides in the prophylaxis of dental caries.

Swedish experts have been considering for a long time the prevention of dental caries by means of fluorides. In 1952 the Swedish Royal Medical Board appointed experts to study the question, and in 1955 the Board reported to the Swedish Government that the addition of fluorides to drinking water would be a valuable means of preventing the widespread dental caries; but the four members of the Scientific Council of the Board were doubtful about possible toxic effects of fluorides, even at the low concentrations present in drinking water, and the Board then preferred to await the outcome of further research. Meanwhile, it recommended the prohibition of fluoridation of public water supplies.

In 1957, however, a committee, consisting of Prof. Sven Sellman, Prof. Yngve Ericsson and Prof. Allan Stralfors, considered the prophylaxis of dental caries with emphasis on the use of fluorides for this purpose. This committee has presented, since 1958, more than one report. Members of the Scientific Council of the Royal Medical Board have also expressed their views. 
There is general agreement that there are three principal methods of prophylaxis of dental caries, namely, administration of fluorides by vehicles other than water supplies, such as tablets, milk, common salt, flour and bone-meal, which the committee cannot recommend until further investigations have been made; topical application of fluoride to the teeth, which should, the committee thinks, be investigated clinically under the control of the Royal Medical Board; and fluoridation of the public water supplies.

With regard to this last method, the Board now reports that fluoridation of public water supplies does not involve any demonstrable hazards to health. It should, however, be carried out under strict control and care should be taken that, where it is instituted, the people are not exposed to fluorides derived from any other sources, such as foods or industrial gases. The Board reports that it has been found that a concentration of about $1 \mathrm{mgm}$. of fluoride per litre of water will reduce the incidence of dental caries by about 50 per cent in children and young persons who have consumed this water all their lives. In other children the caries will be reducer roughly in proportion to the period of consumption of the water. Fluoride also seems to protect the teeth of middle-aged people. A slight mottling of the enamel of the teeth appears in some children who have drunk water containing $1 \mathrm{mgm}$. of fluoride per litre during the period of tooth formation.

The technique of fluoridation of water is simple and has been thoroughly tested, but it is not applic- able to those large groups of people in Sweden who have no access to a public water-supply. In Stockholm and Gothenburg the costs of fluoridation have been estimated at $0 \cdot 3-0.4$ Swedish crowns per person per year, or, when it is restricted to school children, 3-4 crowns per child per year. At present, expenditure on the public dental service for school children is about 75 crowns per child per year, and dental caries is so widespread that all available means of combating it must be used. In Sweden the city of Norrköping fluoridized one of its two public water supplies five years ago, and in Uppsala, Eskiltuna and Hälsingborg the public water supplies naturally contain more fluoride than is used for artificial fluoridation. The Board points out that in other countries in which fluoridation is used no evidence has been found that it harms health, and that both the American Medical Association and the World Health Organization have unreservedly recommended fluoridation as an effective and safe means of preventing dental caries.

The World Health Organization Expert Committee on Water Fluoridation, in its first report*, also concludes that drinking water containing about 1 p.p.m. fluoride has a marked preventive action on caries and does not impair health, and that controlled fluoridation of water is a practicable and effective public health measure.

G. LAPAGE

* World Health Organization. Technical Report Series, No. 146: Expert Committee on Water Fluoridation-First Report. Pp. 25. (Geneva: World Health Organization; London: H.M. Stationery Office, 1958.) 1 Swiss frane; 18, $9 d . ; 0.30$ dollars.

\section{HOST - PARASITE RELATIONSHIPS}

\begin{abstract}
$\mathrm{T}$ HE subject of host - parasite relationships covers such a wide field that the four papers on this subject, presented on September 3 in Section $M$ (Agriculture) of the British Association meeting in Glasgow, not unexpectedly had comparatively little in common. Nevertheless, this diversity of interest helped to emphasize the fact that few living creatures escape the attention of some parasite or other, and that many specialized adaptations are necessary for parasitic life. Equally elaborate defence mechanisms have been evolved by potential hosts. The struggle for survival is governed very largely by the efficiency of these predatory or defending mechanisms.

Dr. J. A. Campbell (Moredun Institute, Edinburgh) explained that, among the insects, the true flies or Diptera apparently adopted the parasitic mode of life comparatively late in their evolutionary history. For this reason the flies show various degrees of adaptation to parasitism which can provide some information on the probable course of development of the habit. Morphological studies provide good evidence that the blood-sucking habit was evolved independently at different times in the various families. The behaviour patterns among the higher flies (Cyclorhapha) suggests that the course of evolution developed from generalized feeding on a wide variety of hosts to a more specialized association within a narrow range of hosts and even to complete dependence on a single species.
\end{abstract}

The stable fly (Stomoxys calcitrans), for example, feeds on a wide range of hosts, including man and most farm animals. Its larvæ can live in a variety of decomposing material, including dung heaps. The horn fly (Lyperosia irritans) is more specialized. The adults feed only on cattle, while the larvæ are confined to cattle dung. In the case of the sheep tick (Melophagus ovinus) dependence on a single host is complete. The fly has no wings, its larvæ are nourished in utero, and pupation occurs on the host.

There are many examples of the development of allergic sensitivity to insect bites. In some cases this can be recognized as a distinct clinical syndrome, such as Queensland itch in horses due to attacks of Culicoides. Insect saliva has been shown to be antigenic and the injection of this saliva can lead to the development of neutralizing antibodies in the host. So far as the hosts of blood-sucking flies are concerned, there is little doubt that for a variety of reasons some members of a species are more resistant to attack than others. There is no evidence, however, that specific immune reactions have any effect on the rate of infestation.

Dr. J. R. Norris (University of Glasgow) discussed the result of some recent work, largely done by two Canadian workers, Hannay and Angus, on the sporebearing bacteria, Bacillus thuringiensis, which infect meal moth larvæ, and Bacillus sotto, which cause a septicæmic disease of silkworms.

Both organisms are capable of developing large protein crystals within their cytoplasm. If silkworm larvæ are fed with cultures of $B$. sotto containing both spores and protein crystals, they first become 